\title{
HIV-associated oral Kaposi sarcoma: a comparison between the immunohistochemistry and qPCR techniques for detection of HHV8
}

\author{
- Priscila Lie Tobouti School of Dentistry, University of São Paulo, São Paulo, SP, Brazil • Juliana Seo School of Dentistry, \\ University of São Paulo, São Paulo, SP, Brazil • Michelle Bezerra Lima School of Health Science, Amazonas State University, \\ Manaus, AM, Brazil • Bruno Tavaris Sedassari School of Dentistry, University of São Paulo, São Paulo, SP, Brazil • Norberto \\ Nubo Sugaya School of Dentistry, University of São Paulo, São Paulo, SP, Brazil • Fabio Daumas Nunes School of Dentistry, \\ University of São Paulo, São Paulo, SP, Brazil • Suzana Cantanhede Orsini Machado Sousa School of Dentistry, University of \\ São Paulo, São Paulo, SP, Brazil
}

ABSTRACT | Objective: To compare the diagnostic accuracy of immunohistochemistry and real-time PCR, using a simple phenol-chloroform DNA extraction protocol, in the detection of HHV8 in small biopsies of HIV-associated oral Kaposi sarcoma (KS). In addition, to validate the use of this DNA extraction protocol to extract HHV8 DNA. Material and methods: Seventeen cases of oral KS were examined. Data including sex, age, and anatomic location were obtained from patients' records and histological sections stained with hematoxylin and eosin (H\&E) were reviewed. Immunohistochemistry was used to detect HHV8 in lesions of interest, as well as real-time PCR. Results: All the patients were HIV positive, the mean age was 35.5 years, and the affected oral sites were the palate (47\%), gingiva (29.4\%), tongue (11.8\%), lip (5.9\%), and oral floor (5.9\%). Fifteen samples showed positive staining for HHV8 and only two samples were negative. The same results were observed using real-time PCR HHV8DNA detection. Relevance: Our findings suggest that immunohistochemistry is faster and cheaper to perform than real-time PCR and was shown to have similar levels of sensitivity and accuracy for the detection of HHV8 even in small biopsies. Additionally, DNA extraction using a non-commercial kit, as done in this study, can further reduce the costs for a pathology service.

DESCRIPTORS | Kaposi Sarcoma; Polymerase Chain Reaction; Immunohistochemistry.

RESUMO || Sarcoma de Kaposi bucal associado ao HIV: Comparação entre as técnicas de imuno-histoquímica e qPCR na detecção do HHV8 - Objetivo: Comparar a acurácia diagnóstica da imuno-histoquímica com a do PCR em tempo real, usando um simples protocolo de extração de DNA por fenol-clorofórmio, na detecção de HHV8 em biópsias pequenas de sarcoma de Kaposi bucal (SK). Material e métodos: Dezessete casos de KS bucais foram examinados. Dados como gênero, idade e localização anatômica foram obtidos, e cortes histológicos corados com hematoxilina e eosina foram revistos. A imuno-histoquímica e o PCR em tempo real foram utilizados para detectar HHV8 nas lesões de interesse. Resultados: Todos os pacientes eram HIV-positivos, com a média de idade de 35,5 anos, e as localizações afetadas foram o palato (47\%), a gengiva (29,4\%), a língua (11,8\%), o lábio (5,9\%) e o assoalho bucal (5,9\%). Quinze amostras apresentaram coloração positiva para HHV8 e apenas duas amostras foram negativas. Os mesmos resultados foram observados utilizando PCR em tempo real.Relevância: Os resultados sugerem que a imuno-histoquímica é mais rápida e mais barata do que PCR em tempo real e mostrou ter níveis semelhantes de sensibilidade e acurácia para a detecção de HHV8, mesmo em pequenas biópsias. Além disso, a extração de DNA usando um kit não comercial, como feito neste estudo, pode reduzir ainda mais os custos em um serviço de patologia.

DESCRITORES | Sarcoma de Kaposi; Reação em Cadeia da Polimerase; Imuno-histoquímica.

CORRESPONDING AUTHOR: | • Priscila Lie Tobouti • Av. Prof. Lineu prestes, 2227 Cidade universitária São Paulo,SP, Brazil • 05508-000 E-mail: pritobouti@usp.br

- Received Apr 14, 2015 • Accepted May 19, 2015

- Dol http://dx.doi.org/10.11606/issn.2357-8041.clrd.2015.97224 


\section{INTRODUCTION}

Kaposi's sarcoma (KS) is a multifocal malignant systemic tumor of endothelial origin, that mainly affects mucocutaneous tissue, with the potential to involve the viscera. ${ }^{1}$ When affecting the oral mucosa, the lesion is locally aggressive but rarely lethal. ${ }^{2}$

The clinical differential diagnoses include bacillary angiomatosis, pyogenic granuloma and some variants of capillary angioma and histological differentiation between those lesions are easily achieved. However, there are certain vascular tumors that are more aggressive and can generate uncertainty in the diagnosis, such as angiosarcomas and epithelioid hemangioendothelioma. ${ }^{3}$

There are three distinct phases of the disease: the macular, plaque and nodular forms. The macular form shows proliferation of small irregular vessels and atypical endothelial cells oriented parallel to the epithelial surface. When the KS appears in plaque form, the morphology is similar to the macular form but with an increased number of spindle cells and intracytoplasmic eosinophilic globules. Finally, nodular lesions are shown to be domeshaped or may be predominantly polypoid with spindle cells arranged in intersecting fascicles. It is common to observe slit-like vascular spaces, small jagged vessels, extravagated erythrocytes, lymphocytes and plasmacytes. The spindle cells usually show ill-defined and eosinophilic cytoplasm. The intracellular lumen can contain erythrocytes and eosinophilic globules. ${ }^{4}$

The association between KS and HHV8 was first described in 1994 when a new herpesvirus sequence was isolated in more than 90 percent of Kaposi sarcoma. ${ }^{5}$ The World Health Organization (WHO) describes KS as a result of human herpesvirus 8 (HHV8) infection combined with immunological, genetic and environmental factors. This virus is not exclusive to this lesion; other cancers, such as AIDS-related primary effusion lymphoma and angioimmunoblastic lymphadenopathy, present HHV8 DNA sequences. ${ }^{6}$

HHV8 is transmitted vertically and horizontally, through oral shedding, transplantation, blood transfusion and drug injection. ${ }^{7}$ It has also been detected in a variety of body fluids and oral exposure to infectious saliva seems to be the prevalent route of transmission.7.8 It can replicate in oral epithelial cells in vitro ${ }^{4}$ and in many cases the mouth is the site of the initial infection.?

Thus, even if the lesion is clinically and histologically similar to KS, it is essential to detect HHV8 in the biopsy. The virus has been extensively studied and identified in a variety of tissues and body fluids. ${ }^{5}$ Many of these studies and pathology services have used immunohistochemistry (IHC) as a standard technique for the detection of HHV8. The use of IHC in small biopsies raises doubts about the results, as oral biopsies could have a low viral load, not being detected by IHC but detected by real-time PCR (qPCR), which is more sensitive.

Our aim was to compare the results of the samples using IHC and qPCR, a sensitive and reliable method to detect HHV8, and to suggest the use of phenol-chloroform DNA extraction protocol to reduce the costs of the technique.

\section{MATERIAL AND METHODS \\ Records and tissue samples}

Ethics approval was obtained from the local Human Research Ethics Committee (Protocol number: 12766213.0.0000.0075). All cases diagnosed as KS or suggested as KS were retrieved from the files of Anatomical Pathology Diagnostic Service at the School of Dentistry of the University of São Paulo and seventeen cases were selected. Data including gender, age, and anatomic location was obtained from patients' records. Histological sections stained with hematoxylin and eosin (H\&E) were reviewed by two pathologists. Subsequently, the material was used 
in IHC and qPCR for detection of HHV8. Staining with an antibody against vimentin was also used to check on the viability of the material for immunohistochemistry. The results of IHC and qPCR were truly dichotomous (positive or negative) and interpreted by three blinded observers.

\section{Immunohistochemistry for HHV8}

Three-micrometer (3 $\mathrm{mm})$ serial sections from formalin-fixed paraffin-embedded blocks were obtained and mounted on polyL-lysine-coated glass slides. Immunostaining was performed by the linked streptavidin-biotin horseradish peroxidase technique (LSABHRP) (Universal LSAB $R+$ Kit/HRP, DAKO Carpinteria, CA, USA). The samples were deparaffinized in xylene, then hydrated in descending ethanol grades and finally treated with $0.3 \%$ $\mathrm{H}_{2} \mathrm{O}_{2}$ and $100 \%$ methanol for $15 \mathrm{~min}$ to quench endogenous peroxidase. Antigen retrieval was performed by heating specimens for $15 \mathrm{~min}$ at $95^{\circ} \mathrm{C}$ in $10 \mathrm{mM}$ Tris-EDTA buffer ( $\mathrm{pH}$ 9.0) for HHV8-LNA and in $10 \mathrm{mM}$ citric acid for vimentin. Sections were incubated overnight at $4^{\circ} \mathrm{C}$ with primary monoclonal anti-HHV8 antibody (clone 13B10, 1:10 dilution, Novocastra Lab, Newcastle upon Tyne, United Kingdom) and primary monoclonal anti-vimentin antibody (clone V9, 1:80o dilution, Dako, Glostrup, Denmark). After three washes with Tris buffer, slides were treated with biotinylated species-specific secondary antibodies and streptavidin-biotin enzyme reagent (Universal LSAB ${ }^{\mathrm{TM}}$ Kit/HRP, Dako, Carpinteria, CA, USA). Color was developed with 3,3'-diaminobenzidine tetrahydrochloride chromogen solution (Liquid DAB+ SubstrateChromogen System, Dako, Carpinteria, CA, USA). Sections were counterstained with Mayer's haematoxylin (Sigma-Aldrich, St. Louis, MO, USA). The results were evaluated separately by three investigators.

\section{DNA extraction and real-time PCR}

DNA from the lesions diagnosed as KS or suggestive of it was isolated using the phenol-chloroform extraction protocol adapted from Isola et al., $1994 .{ }^{9}$ For this, ten sections of $10 \mu \mathrm{m}$ from formalin-fixed, paraffin-embedded blocks were obtained and placed in a microtube. Tissue sections were deparaffinized with $1 \mathrm{~mL}$ of pre-heated xylene (Sigma-Aldrich, Saint Louis, MO, USA) at $37^{\circ} \mathrm{C}$ for $30 \mathrm{~min}$. Afterwards, contents were vortexed, centrifuged and the supernatant was discarded. This procedure was repeated three or more times until paraffin was completely removed. Residual xylene was eliminated by washing with descending grades of ethanol, starting with absolute ethanol (Synth, Diadema, SP, Brazil), 90\%, 70\%, Milli-Q water and finally with Tris-EDTA buffer (SigmaAldrich, St. Louis, MO, USA). Microtubes were centrifuged and the Tris-EDTA was discarded. Subsequently, $200 \mu \mathrm{L}$ of lysis solution was added (10 mM Tris-HCl, $25 \mathrm{mM}$ EDTA, $100 \mathrm{mM} \mathrm{NaCl}$, $0.5 \%$ SDS, $500 \mu \mathrm{g} / \mathrm{mL}$ ) (Sigma-Aldrich, St. Louis, $\mathrm{MO}$, USA) and the microtubes were left overnight in a $56^{\circ} \mathrm{C}$ water bath. Following this, $20 \mu \mathrm{L}$ of 250 $\mu \mathrm{g} / \mathrm{mL}$ Proteinase $\mathrm{K}$ (Invitrogen, Carlsbad, CA, USA) was added daily until the tissue was completely lysed (three days maximum). To inactivate proteinase $\mathrm{K}$, samples were heated at $95^{\circ} \mathrm{C}$ for 10 minutes. For DNA extraction, $1 \mathrm{~mL}$ of saturated phenol (Invitrogen, Carlsbad, CA, USA), pH 8.0, was added to the previous tube, then vortexed and centrifuged at top speed. The supernatant (upper phase) was removed and transferred into a new microtube. Next, $1 \mathrm{~mL}$ of Phenol:Chloroform:Alcohol (Invitrogen, Carlsbad, CA, USA) (25:24:1) was added and centrifuged, and the upper phase was removed to new microtube. For DNA precipitation, 2 volumes of cold absolute ethanol $\left(-20^{\circ} \mathrm{C}\right)$ and $1 / 10^{\text {th }}$ volume of $7 \mathrm{M}$ ammonium acetate (SigmaAldrich, St. Louis, MO, USA) were added and the tubes rested overnight at $-20^{\circ} \mathrm{C}$. After $18 \mathrm{~h}$, 
the microtubes were centrifuged at top speed and the supernatant discarded. The pellet was washed with $70 \%$ ethanol and dried at room temperature. The DNA pellet was dissolved in $50 \mu \mathrm{l}$ of Tris-EDTA and kept at $-20^{\circ} \mathrm{C}$ before use. Realtime PCR was performed on DNA using $\mathrm{SYBR}^{\circledR}$ Green Master Mix (Life Technologies, Carlsbad, CA, USA) and a thermocycler (Applied Biosystems 750o Real-Time PCR System).

Primers for HHV8 ${ }^{(10)}$ and GAPDH ${ }^{(11)}$ are shown in Table 1. The sequences were chosen and tested to find regions of local similarity using the Basic Local Alignment Search Tool (BLAST).

The conditions of the real-time PCR reaction were: $12.5 \mu \mathrm{L}$ of $\mathrm{SYBR}^{\circledR}$ Green Master Mix; 1.0 $\mu \mathrm{L}$ of each $400 \mathrm{nM}$ primer; $9.5 \mu \mathrm{L}$ of ultrapure water (Milli-Q, $18 \Omega$ Millipore) and 1.0 $\mu \mathrm{L}$ of the DNA sample (100 ng of total DNA). The program for amplification included initial denaturation at $95^{\circ} \mathrm{C}$ for 5 minutes, followed by 40 cycles at $95^{\circ} \mathrm{C}$ for $15 \mathrm{sec}$ and $60^{\circ} \mathrm{C}$ for $1 \mathrm{~min}$. The reaction specificity was monitored by melt-curve analysis. DNase/ RNase-free water was used as negative control, while a sample positive for HHV8, by immunohistochemistry, was used as positive control. GAPDH was used as a housekeeping gene and to verify the integrity of the purified DNA from the formalin-fixed, paraffin-embedded blocks.

\section{RESULTS}

\section{Records}

All patients were HIV-positive and there was a male prevalence (13/17). The mean age was 37.69 years (ranging from 23 to 58 ) and the affected oral sites in order of frequency were: palate (47.05\%), gingiva (29.41\%), tongue (11,76\%), lip (5.89\%) and oral floor (5.89\%). The biopsy material was represented by small fragments measuring in average $3.82 \times 2.18 \mathrm{~mm}$ (Table 2).

Concordance analysis of HHV8 detection by immunohistochemistry and HHV8 DNA molecular method (real-time PCR)

Fifteen samples showed positive staining for HHV8 (Figure 1) and only two samples were negative. All the tissues were positive for vimentin. The same results were observed using HHV8 DNA detection; fifteen cases identified viral DNA and two cases were undetermined. All samples amplified the endogenous control GAPDH.

Table 1 | Primers used to detect HHV8 and GAPDH (real-time PCR).

\begin{tabular}{|c|c|c|c|c|}
\hline Gene & Accession no. & Primer 5'-3' & Position & $\begin{array}{l}\text { Size } \\
\text { (bp) }\end{array}$ \\
\hline \multirow[t]{2}{*}{ HHV8(10) } & NC_003409 & F:GGTGATGTTCTGAGTACATAGCGG & $\begin{array}{c}124,326- \\
124,349\end{array}$ & \multirow{2}{*}{142} \\
\hline & & R: CCGAGGACGAAATGGAAGTG & $\begin{array}{c}124,467- \\
124,448\end{array}$ & \\
\hline \multirow[t]{2}{*}{ GAPDH(11) } & NM_002046 & F: GCATCCTGGGCTACACTGA & $917-936$ & \multirow{2}{*}{162} \\
\hline & & R: CCACCACCCTGTTGCTGTA & $1059-1078$ & \\
\hline
\end{tabular}


Table 2 | Clinical data of the patients (gender, age and site of biopsy), HHV8 detection by immunohistochemistry and qPCR, and size of biopsy material.

\begin{tabular}{|c|c|c|c|c|c|c|c|}
\hline Sample & Gender & Age (years) & Site & HIV & HHV8(IHC) & HHV8(qPCR) & $\begin{array}{l}\text { Size of biopsy } \\
\text { material }(\mathrm{mm})\end{array}$ \\
\hline 1 & M & 30 & Gingiva & + & + & + & $4 \times 2$ \\
\hline 2 & $\mathrm{~F}$ & 23 & Floor & + & + & + & $10 \times 5$ \\
\hline 3 & M & 30 & Palate & + & + & + & $4 \times 4$ \\
\hline 4 & $\mathrm{~F}$ & 37 & Lip & + & + & + & $2 \times 1$ \\
\hline 5 & M & 45 & Palate & + & + & + & $6 \times 2$ \\
\hline 6 & M & 43 & Palate & + & + & + & $5 \times 2$ \\
\hline 7 & M & 43 & Palate & + & + & + & $5 \times 3$ \\
\hline 8 & M & 32 & Gingiva & + & + & + & $2 \times 1$ \\
\hline 9 & M & 58 & Tongue & + & + & + & $3 \times 2$ \\
\hline 10 & $\mathrm{~F}$ & 27 & Gingiva & + & + & + & $3 \times 1$ \\
\hline 11 & M & 36 & Palate & + & + & + & $3 \times 3$ \\
\hline 12 & M & 38 & Gingiva & + & + & + & $3 \times 1$ \\
\hline 13 & M & 32 & Palate & + & + & + & $4 \times 2$ \\
\hline 14 & $\mathrm{~F}$ & 27 & Palate & + & + & + & $2 \times 1$ \\
\hline 15 & M & 25 & Gingiva & + & + & + & $3 \times 3$ \\
\hline 16 & M & 43 & Tongue & + & - & - & $4 \times 2$ \\
\hline 17 & $M$ & 34 & Palate & + & - & - & $2 \times 2$ \\
\hline
\end{tabular}

M: Male; F: Female

Figure 1 | Kaposi sarcoma: haematoxylin \& eosin (A) and immunohistochemistry detection of HHV8 (B, C and D). 400x.

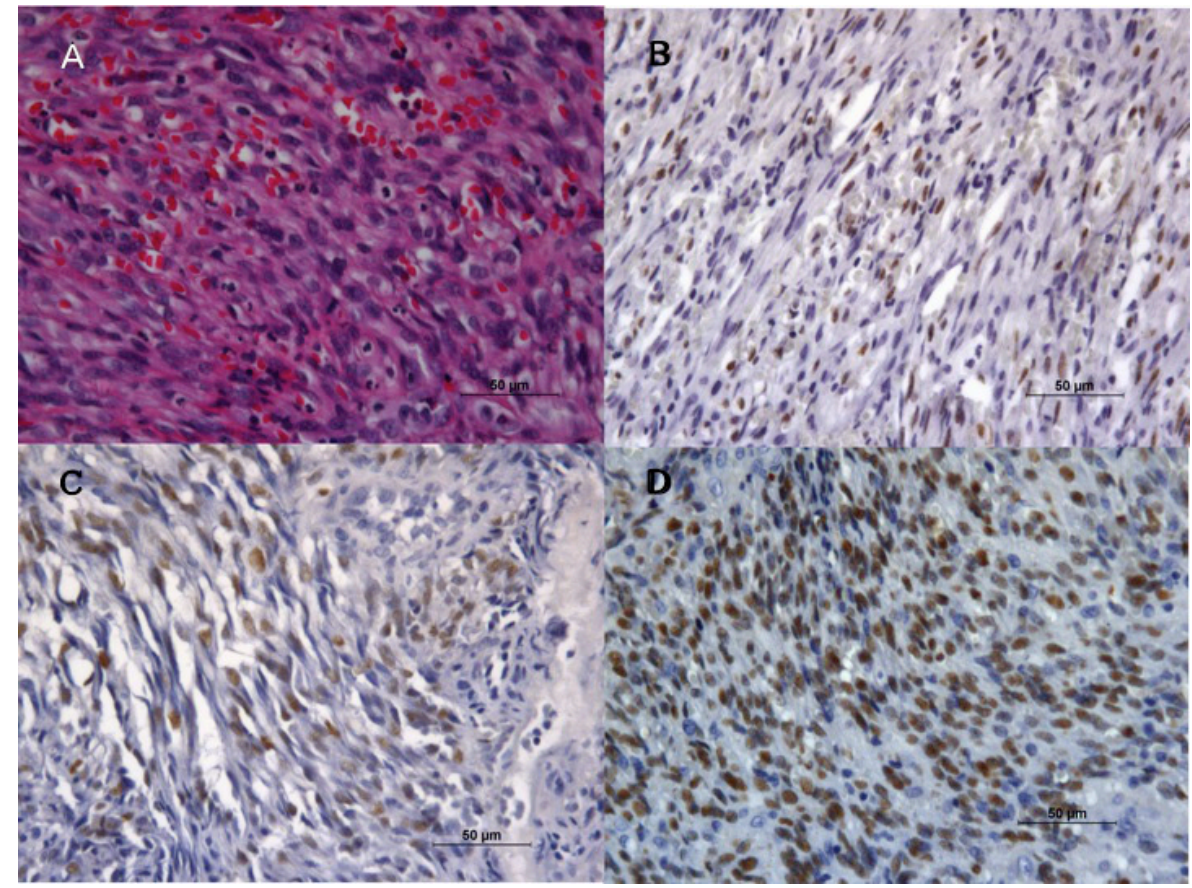




\section{DISCUSSION}

$\mathrm{KS}$ is an angioproliferative disorder of the vascular endothelium ${ }^{12,13}$ and is one of the most frequent tumors in HIV-positive patients worldwide. ${ }^{2,14}$ Oral KS is strongly indicative of HIV infection and can be an early presenting symptom. ${ }^{15}$

HHV8 is the causative agent of Kaposi sarcoma, ${ }^{7,13}$ but it is not sufficient to develop the disorder alone and a cofactor, such as HIV, may exist.? The most common mode of transmission of this virus is via oral cavity, through saliva, ${ }^{7,8}$ and it can replicate in oral epithelial cells in vitro. ${ }^{16}$

Small biopsies from the oral cavity can be a challenge to diagnose and this raises questions and doubts about the best method to detect HHV8. Our samples sizes were typical of the small sizes frequently received by oral pathologists. When a biopsy is performed, there are no strict size criteria, but tiny samples may lead to a poor quality slide, especially when the correlation of different tissues is important to the final diagnosis. ${ }^{17,18}$ In KS, histomorphology is important and all cases, irrespective of epidemiologic subgroup, must be HHV8-positive for a proper diagnosis. ${ }^{19}$

In contrast to other studies that used or suggested other techniques ${ }^{20,21,22}$ besides IHC to detect HHV8, in our work, IHC was found to be as efficient as qPCR to identify HHV8 in small biopsies of oral KS. This was verified in all samples in which a concordance between the results of IHC and qPCR was found. Fifteen cases were shown to be positive for HHV8 by both techniques, confirming the diagnosis of Kaposi sarcoma. Only two samples were negative, but negative by both techniques, showing an agreement in the results. These negative results could be due to a lack of viral material, possibly because it is a non-representative biopsy, or could represent another angioproliferative lesion, but neither of the methods detected HHV8. Patients' records often lacked information, as all patients were HIV+ but there was no indication of what treatment they were using. Antiretroviral drugs such as HAART can be potent inhibitors of HHV8 replication. ${ }^{23}$

Our results also showed that the phenol-chloroform extraction protocol is efficient for HHV8 DNA extraction. Previous papers from our group showed that the extraction method using this protocol and ammonium acetate proved to be simple to perform and obtains DNA of adequate quality for analysis. ${ }^{24}$

Although IHC and qPCR can be routinely used to diagnose $\mathrm{KS}$, there are some advantages using IHC, especially the lower cost, since qPCR demands more sophisticated and expensive equipment and reagents. The use of a non-commercial method for DNA extraction decreases the cost but increases the time of procedure. In addition, both methods may present technical challenges when using formalin-fixed, paraffin-embedded material, which may be fragmented or have undergone formaldehyde cross-reaction with proteins and nucleic acids. ${ }^{25}$

It was showed that, despite the size of the biopsies, IHC seems to be a reliable method to diagnose oral KS. The adapted phenol-chloroform extraction protocol should also be considered because of its lower cost, especially in underdeveloped countries where a commercial DNA extraction kit is extremely expensive.

\section{ACKNOWLEDGEMENT}

The authors would like to thank Conselho Nacional de Desenvolvimento Científico e Tecnológico (CNPq) for the financial support.

\section{REFERENCES}

1. Mehta S, Garg A, Gupta LK, et al. Kaposi's sarcoma as a presenting manifestation of HIV. Indian J Sex Transm Dis. 2011 Jul;32:108-10.

2. Khammissa RA, Pantanowitz L, Feller L. Oral HIV-Associated Kaposi Sarcoma: A Clinical Study from the Ga-Rankuwa Area, South Africa. AIDS Res Treat. 2012 Sep;2012: 873171. 
3. Nakamura S, Salahuddin SZ, Biberfeld P, et al. Kaposi's sarcoma cells: long-term culture with growth factor from retrovirusinfected CD4+ T cells. Science. 1988 Oct;242:426-30.

4. Reis-Filho JS, Souto-Moura C, Lopes JM. Classic Kaposi's sarcoma of the tongue: case report with emphasis on the differential diagnosis. J Oral Maxillofac Surg. 2002 Aug;60:951-4.

5. Chang Y, Cesarman E, Pessin MS, et al. Identification of herpesvirus-like DNA sequences in AIDS-associated Kaposi's sarcoma. Science. 1994 Dec;266:1865-9.

6. Ablashi DV, Chatlynne LG, Whitman JE Jr., et al. Spectrum of Kaposi's sarcoma-associated herpesvirus, or human herpesvirus 8, diseases. Clin Microbiol Rev. 2002 Jul;15:439-64.

7. Mesri EA, Cesarman E, Boshoff C. Kaposi's sarcoma and its associated herpesvirus. Nat Rev Cancer. 2010 Oct;10:707-19.

8. Pauk J, Huang ML, Brodie SJ, et al. Mucosal shedding of human herpesvirus 8 in men. N Engl J Med. 2000 Nov;343:1369-77.

9. Isola J, DeVries S, Chu L, et al. Analysis of changes in DNA sequence copy number by comparative genomic hybridization in archival paraffin-embedded tumor samples. Am J Pathol. 1994 Dec;145:1301-8.

10. Lallemand F, Desire N, Rozenbaum W, et al. Quantitative analysis of human herpesvirus 8 viral load using a realtime PCR assay. Journal of Clinical Microbiology. 2000 Apr;38:1404-8.

11. Campos MS, Rodini CO, Pinto-Junior DS, et al. GAPD and tubulin are suitable internal controls for qPCR analysis of oral squamous cell carcinoma cell lines. Oral Oncology. 2009 Feb;45:121-6.

12. Fatahzadeh M. Kaposi sarcoma: review and medical management update. Oral Surg Oral Med Oral Pathol Oral Radiol. 2012 Jan;113:2-16.

13. Van der Waal I, Lamovec J, Knuutila S. Kaposi sarcoma. In: World Health Organization. Pathology \& Genetics: Head and Neck Tumors. Albany: WHO publications Center; 2005. (IARC WHO Classification of Tumours)

14. Pantanowitz L, Khammissa RA, Lemmer J, Feller L. Oral HIV-associated Kaposi sarcoma. Journal of oral pathology \& medicine : official publication of the International Associa- tion of Oral Pathologists and the American Academy of Oral Pathology. 2013 Mar;42(3):201-7

15. Coogan MM, Greenspan J, Challacombe SJ. Oral lesions in infection with human immunodeficiency virus. Bull World Health Organ. 2005 Sep:83:700-6.

16. Duus KM, Lentchitsky V, Wagenaar T, et al. Wild-type Kaposi's sarcoma-associated herpesvirus isolated from the oropharynx of immune-competent individuals has tropism for cultured oral epithelial cells. J Virol. 2004 Apr;78:4074-84.

17. Avon SL, Klieb HB. Oral soft-tissue biopsy: an overview. J Can Dent Assoc. 2012 Jul;78:c75.

18. Melrose RJ, Handlers JP, Kerpel S, et al. The use of biopsy in dental practice. The position of the American Academy of Oral and Maxillofacial Pathology. Gen Dent. 2007 Sep;55:457-61.

19. Stiller CA, Trama A, Brewster DH, et al. Descriptive epidemiology of Kaposi sarcoma in Europe. Report from the RARECARE project. Cancer Epidemiol. 2014 Dec;38:670-8.

20. Betsem E, Cassar O, Afonso PV, et al. Epidemiology and genetic variability of HHV-8/KSHV in Pygmy and Bantu populations in Cameroon. PLoS Negl Trop Dis. 2014 May;8:e2851.

21. Chagas CA, Endo LH, Sakano E, et al. Detection of herpesvirus type 8 (HHV8) in children's tonsils and adenoids by immunohistochemistry and in situ hybridization. Int $\mathrm{J}$ Pediatr Otorhinolaryngol. 2006 Jan;70:65-72.

22. Pinheiro RS, Ferreira DC, Nobrega F, et al. Current status of herpesvirus identification in the oral cavity of HIV-infected children. Rev Soc Bras Med Trop. 2013 Jan-Feb;46:15-9.

23. Cattamanchi A, Saracino M, Selke S, et al. Treatment with valacyclovir, famciclovir, or antiretrovirals reduces human herpesvirus-8 replication in HIV-1 seropositive men. J Med Virol. 2011 Oct;83:1696-703.

24. Rivero ER, Neves AC, Silva-Valenzuela MG, et al. Simple salting-out method for DNA extraction from formalinfixed, paraffin-embedded tissues. Pathol Res Pract. 2006 May;202:523-9.

25. Campos PF, Gilbert TM. DNA extraction from formalin-fixed material. Methods Mol Biol. 2012 Dec;840:81-5. 